\title{
Improving Almond Productivity under Deficit Irrigation in Semiarid Zones
}

\author{
I.F. García-Tejero, V.H. Durán-Zuazo*, L.M. Vélez, A. Hernández, A. Salguero and \\ J.L. Muriel-Fernández
}

Centro IFAPA 'Las Torres-Tomejil’ Ctra. Sevilla-Cazalla Km. 12,2 41200, Alcalá del Río (Sevilla), Spain

\begin{abstract}
Sustainable water use is one of the greatest challenges of irrigated agricultural systems. This study presents the results related to the agronomic and physiological response to the deficit irrigation of almond trees (Prunus dulcis DA Webb Mill cv. Guara) under semiarid Mediterranean conditions in the Guadalquivir river basin (SW Spain). Two deficitirrigation strategies were tested: i) regulated deficit irrigation (RDI), which was irrigated at $100 \%$ of crop evapotranspiration $\left(\mathrm{ET}_{\mathrm{C}}\right)$ throughout the irrigation period, except during the kernel-filling stage, when these trees where irrigated at $30 \% \mathrm{ET}_{\mathrm{C}}$, and ii) low-frequency deficit irrigation (LFDI), in which trees were subjected to different irrigationrestriction periods, defined in terms of stem water potential at midday $\left(\Psi_{\mathrm{Stem}}\right)$. As control, a fully irrigated treatment $(\mathrm{C}$ $100)$ was used, which received irrigation covering the $100 \%$ of $\operatorname{ET}_{C}$. The stem water potential $\left(\Psi_{\text {Stem }}\right)$, the stomatal conductance $\left(\mathrm{g}_{\mathrm{S}}\right)$, the photosynthesis rate $(\mathrm{Pn})$ and canopy temperature $\left(\mathrm{T}_{\mathrm{C}}\right)$ were monitored, revealing significant differences mainly in LFDI in comparison with C-100. Also, highly significant relationships were found among plant physiological parameters, showing that the water status is strongly related to the crop water availability. On other hand, in terms of nut yield, there was a notable improvement under LFDI compared with RDI, with increases of $16 \%$ in relation to $\mathrm{C}-100$, and with water savings of close to $170 \mathrm{~mm}$. Thus, these findings demonstrate that the LFDI is a sustainable strategy to improve almond productivity as well as water-use efficiency under limited water resources.
\end{abstract}

Keywords: Almond orchards, deficit irrigation, water stress, water-use efficiency.

\section{INTRODUCTION}

Almond (Prunus dulcis), covering more than 650,000 ha in Spain, is the country's third largest crop in growing area, after olive and grape [1]. However, profits are relatively low, this being a representative woody crop to which few resources are dedicated.

The implementation of new irrigation systems in rainfed farming areas is an alternative and opportunity to improve the productivity and viability of this tree crop. For this, under semiarid conditions, the most limiting factor is water to cover crop demands.

Although almond, being highly drought tolerant, has traditionally been associated with marginal rainfed areas, this crop under non-limiting conditions would offer significantly improved yield with a high economic return. In this context, in the San Joaquin Valley (California, USA), with irrigation rates of close to $12,000 \mathrm{~m}^{3} \mathrm{ha}^{-1} \mathrm{yr}^{-1}$, almond trees reach yields of up to 10 times higher than under rainfed conditions [2].

This crop has been repeatedly linked to extreme waterstress situations, being grown in many areas under rainfed conditions, and excellent adaptability to different situations of water availability has been reported [3, 4], non-limiting water conditions significantly boosting yield and kernel quality [5-7].

*Address correspondence to this author at the IFAPA Centro Las TorresTomejil Junta de Andalucía Ctra. Sevilla-Cazalla, Km 12.241200 Alcalá del Río (Sevilla), Spain; Tel: +34 955.045.578; Fax: +34 955.045.624; Email: victorh.duran@juntadeandalucia.es
However, in areas where water is limited, a viable compromise between full irrigation and rainfed conditions is deficit irrigation (DI), providing acceptable crop-yield levels similar to those achieved under non-limiting water conditions and thus improving those reached under rainfed situations $[8,9]$.

Many mathematical expressions have been proposed in relation to water-use efficiency (WUE) and crop-water productivity, generally from an agricultural perspective. This parameter is related to the output:input ratio in an agroecosystem, more specifically, relating the amount of biomass production to water consumption by the crop $[10,11]$. It is well known that WUE can be altered by water regimes. Although WUE frequently decreases under water deficit [12], it is possible in arid and semi-arid areas, with significant water scarcity, to increase these values under different strategies of DI [13]. Clearly, WUE depends not only on the total water applied but also when and how it is applied.

The knowledge of plant response to environmental conditions is a key factor for proper irrigation scheduling and optimization. Traditionally, we have used measures based on the soil or atmospheric variables for proper irrigation management and scheduling. The use of plant-based water-stress indicators for monitoring the effects of DI has been widely studied in several crops to reduce risks of crop failure or tree damage by water stress. In this sense, stemwater potential $\left(\Psi_{\text {stem }}\right)$ and stomatal conductance $\left(\mathrm{g}_{\mathrm{S}}\right)$ are the most commonly used parameters to monitor the plant-water status, when the crop is subjected to water stress, although these measurements are time consuming and cannot be 
automated, hampering continuous monitoring [14-16]. The canopy temperature $\left(\mathrm{T}_{\mathrm{C}}\right)$ measured with infrared thermometry or other remote infrared sensors can be used as a technique for monitoring plant-water status under DI. In this sense, canopy-surface temperatures provide a reliable indicator for detecting plant-water stress, and are closely related to daily transpiration [17-19].

The aim of this study was to assess the nut yield and physiological responses of almond trees subjected to two deficit-irrigation strategies in a semiarid region, analyzing the relationships of physiological parameters for monitoring the plant-water status.

\section{MATERIAL AND METHODS}

\section{Location and Experimental Design}

The trial was made in an experimental plot of mature almonds (Prunus dulcis Mill. D.A. Webb cv. Guara), located in the Guadalquivir river basin $\left(37^{\circ} 30^{\prime} 47^{\prime}\right.$ ' $\mathrm{N} ; 5^{\circ} 58^{\prime} 2^{\prime}$ ' $\mathrm{O}$ ) (Seville, SW Spain). The trees had been planted in 2000, and spacing $6 \times 7 \mathrm{~m}$, under drip irrigation with two pipe lines with emitters of $4 \mathrm{~L} \mathrm{~h}^{-1}$, and 14 emitters per tree.

The soil of the experimental plot was deep $(>2.5 \mathrm{~m})$, with a silty-loam texture. The organic-matter content was low $\left(<15.0 \mathrm{~g} \mathrm{~kg}^{-1}\right)$, for a water-holding capacity of $0.17 \mathrm{~m}^{3}$ $\mathrm{m}^{-3}$. The roots were located predominately in the first $50 \mathrm{~cm}$ of soil, although these exceed one $\mathrm{m}$ in depth.

The climatology in the study area is typically semi-arid Mediterranean, with an annual evapotranspiration rate $\left(\mathrm{ET}_{0}\right)$ of 1,200 $\mathrm{mm}$ and an accumulated rainfall of $550 \mathrm{~mm}$, these being distributed from October to April, for an accumulated water deficit of nearly $700 \mathrm{~mm} \mathrm{yr}^{-1}$.
Two deficit irrigation treatments were applied: i) a regulated deficit-irrigation treatment (RDI), which received the $100 \%$ of crop evapotranspiration $\left(\mathrm{ET}_{\mathrm{C}}\right)$ during the irrigation period, except during the kernel-filling stage, when this treatment was irrigated at $50 \%$ of $\mathrm{ET}_{\mathrm{C}}$, and ii) a low frequency-deficit irrigation (LFDI), in which trees were subjected to different irrigation-restriction periods, defined in terms of stem-water potential at midday $\left(\Psi_{\text {Stem }}\right)$. As in the previous treatment, this was irrigated at $100 \% \mathrm{ET}_{\mathrm{C}}$ throughout the irrigation period, except during kernel filling. In this case, when $\Psi_{\text {Stem }}$ values approached a threshold value of $-2.0 \mathrm{MPa}$, these trees were irrigated at $100 \%$ of $\mathrm{ET}_{\mathrm{C}}$. On the other hand, when these values were similar to those detected in well-watered almond trees, these were subjected to restriction periods until the $\Psi_{\text {Stem }}$ threshold value was again reached. Additionally, a fully irrigated treatment $(\mathrm{C}$ 100 , i.e. irrigated at $100 \%$ of $\mathrm{ET}_{\mathrm{C}}$ ) was used as a control. The DI treatments and control were displayed in a randomizedblock design with three replicates. Each plot had 10 trees per row, the five central trees of the rows being used for nutyield and physiological measurements while the other five trees served as border trees.

\section{Field Measurements}

During the experimental period the $\Psi_{\text {Stem }}$ was measured in two leaves per sampling tree, between 11:00 and 12:00 h solar time, and every 5-7 days. $\Psi_{\text {Stem }}$ was monitored in shaded mature leaves close to the north quadrant and near the trunk, using a pressure chamber [20], following Turner [21] protocol (Fig. 1)

With the same periodicity, stomatal conductance $\left(\mathrm{g}_{\mathrm{S}}\right)$ and photosynthesis rate $\left(\mathrm{P}_{\mathrm{n}}\right)$ were measured in two sunny leaves per tree, using a diffusion porometer AP-4 (Delta-T Devices,

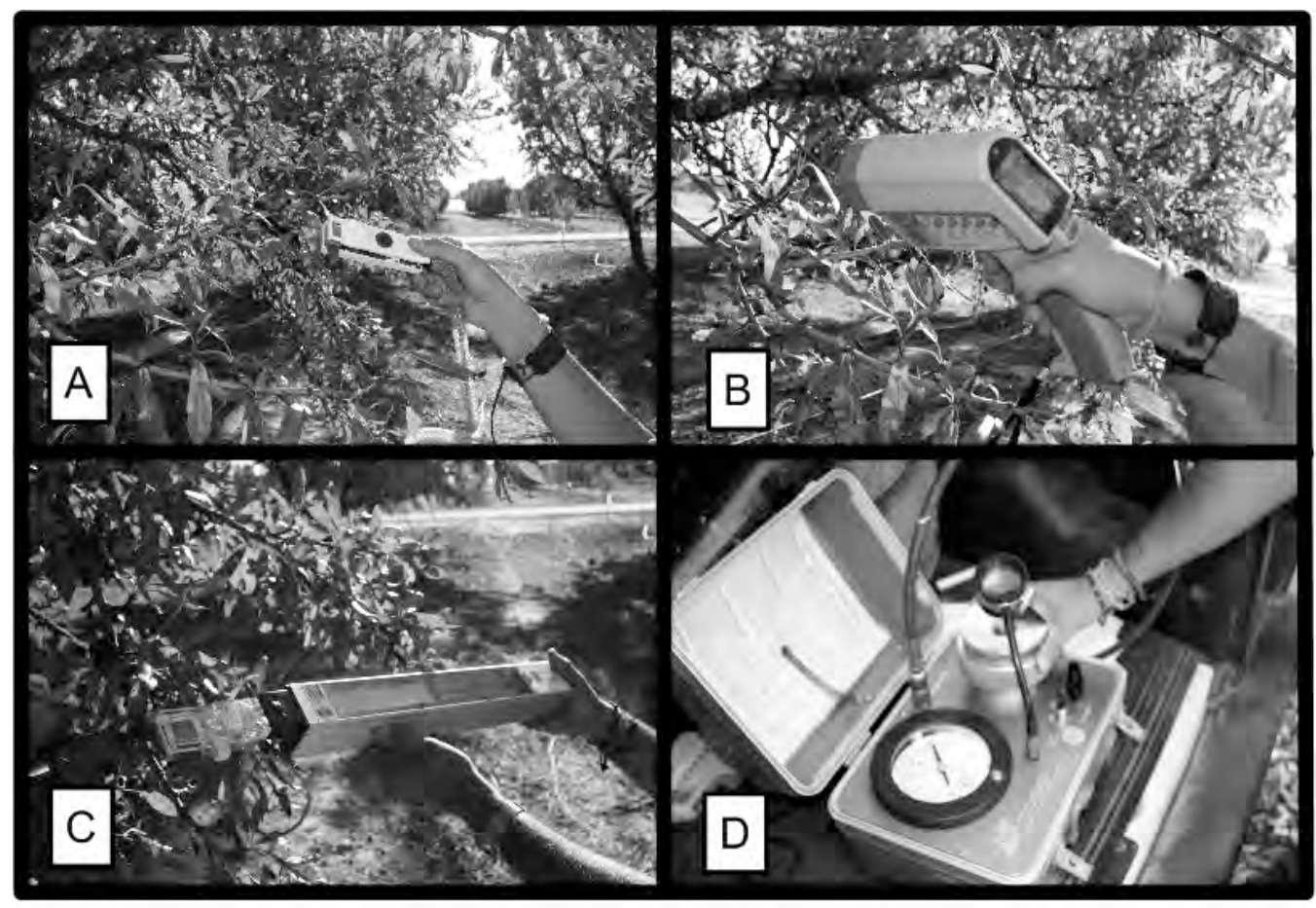

Fig. (1). Devices used for field measurement: the stomatal conductance (A), canopy temperature (B), photosynthesis rate (C) and stem-water potential (D). 
Cambridge, UK) and a Photosynthesis system (CI-340, CID, Inc.), respectively. Finally, canopy-temperature readings were made with a thermal infrared thermometer (Raytek, MX) with the same periodicity as the previous readings.

Additionally, the volumetric soil-water content $\left(\theta_{\mathrm{V}}\right)$ was measured at different soil depths $(10,20,30,60$, and 100 $\mathrm{cm}$ ) using a Frequency Domain Reflectometry (FDR) probe (Mod. PR2, Delta-T).

Finally, nut yield was measured by harvesting four trees per treatment, whereupon the fruit and kernel weight were recorded.

\section{Data Analysis}

An exploratory and descriptive analysis was made for $\Psi_{\text {Stem }}, g_{S} T_{C}$, and $P_{n}$, followed by analysis of variance (ANOVA) with a mean separation analysis, $(p<0.05)$. Additionally, these variables were correlated, evaluating the viability of these readings as plant-based water-stress indicators for monitoring the effects of DI, establishing the physiological threshold values during the application of water stress.

\section{RESULTS AND DISCUSSION}

During the monitoring period (151-220 DOY), treatments received irrigation water amounts according to the experimental design. Control trees received water amounts similar to $100 \% \mathrm{ET}_{\mathrm{C}}$, whereas $\mathrm{RDI}$ received approximately, a $50 \%$ $\mathrm{ET}_{\mathrm{C}}$. In the case of LFDI, this was subjected to three restriction periods, one from 151 to 159 DOY; the second from 166 to 175 DOY; and the third from 196 to 215 DOY (Fig. 2).

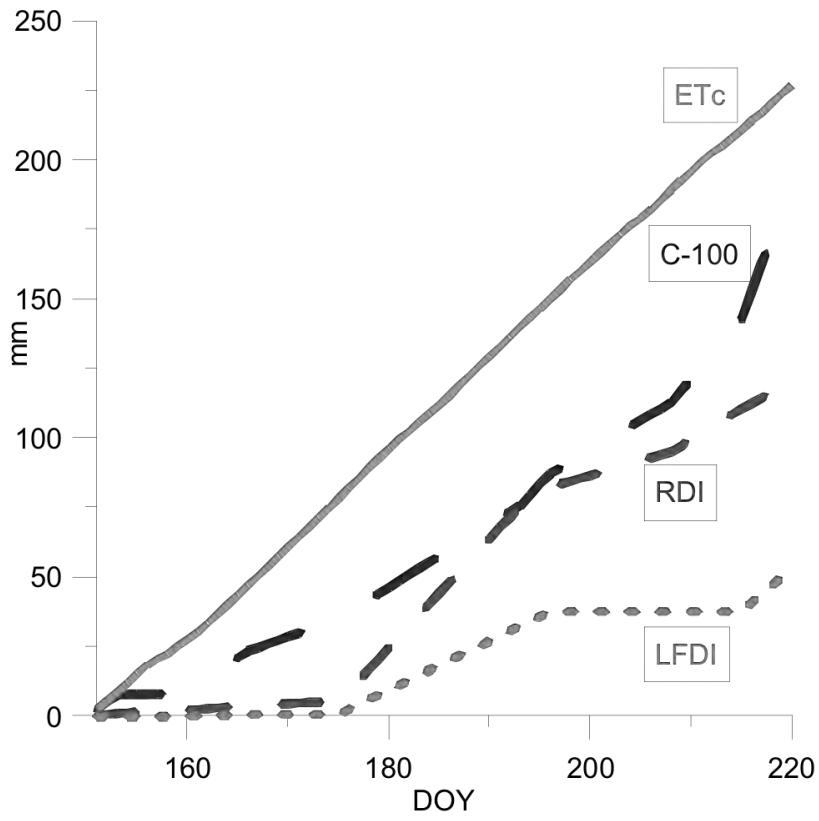

Fig. (2). Crop water evapotranspiration $\left(\mathrm{ET}_{\mathrm{C}}\right)$ and irrigation water amounts applied in each treatment. C-100, control treatment; RDI, regulated deficit-irrigation treatment; LFDI, low-frequency deficitirrigation treatment.

The $\Psi_{\text {Stem }}$ as the $g_{S}$ under DI treatments registered significant differences with $\mathrm{C}-100$, these being especially remarkable in LFDI during the restriction periods. In this context, partial recoveries were observed during the irrigation periods in both physiological variables (Fig. 3). Regarding to RDI, these differences were not noticeable as in LFDI. This situation could be explained through the crop capability for adapting to water-stress situations or considering the situation of the experimental plot, near to the Guadalquivir riverbed. The $\Psi_{\text {Stem }}$ values in C-100 ranged between -0.8 and $-1.3 \mathrm{MPa}$, these values being in line with those reported by other authors under non-limiting water availability $[14,22]$. On the other hand, $\Psi_{\text {Stem }}$ in RDI were similar to those measured in C-100, except on certain days with temperatures of up to $40^{\circ} \mathrm{C}$. Finally, LFDI showed the highest fluctuations with similar values to those of control trees during the recovery periods, and $\Psi_{\text {Stem }}$ values fell below to $-2.5 \mathrm{MPa}$.

The $g_{\mathrm{S}}$ readings showed a similar pattern to $\Psi_{\text {Stem }}$, with values of between 210 and $520 \mathrm{mmol} \mathrm{m}^{-2} \mathrm{~s}^{-1}$ in control trees, and significant differences for LFDI and RDI, as was determined for $\Psi_{\text {Stem. }}$. Major declines in $g_{S}$ values for RDI and LFDI were detected from 183 DOY, when these values dropped below to $100 \mathrm{mmol} \mathrm{m}^{-2} \mathrm{~s}^{-1}$. These results imply that high water-stress levels are necessary to prompt a clear response in terms of $g_{\mathrm{S}}$ and $\Psi_{\mathrm{Stem}}$, as observed by Romero et al., [23].

Regarding both the temporal variation of $\mathrm{P}_{\mathrm{n}}$ and the $\mathrm{T}_{\mathrm{C}}$, these values followed similar trends as those of $\Psi_{\text {Stem }}$ and $g_{s}$ (Fig. 4).

Significant differences in $T_{C}$ were substantially greater than those previously found for $\Psi_{\mathrm{Stem}}$ and $\mathrm{g}_{\mathrm{s}}$. In this sense, García-Tejero et al., [24] reported higher sensitivity variations in the $T_{C}$ in response to water deficit, in contrast to $\Psi_{\text {Stem }}$ or $\mathrm{g}_{\mathrm{s}}$.

In terms of $\Psi_{\text {Stem }}$ and $g_{s}$, the RDI treatment showed significant differences with respect to control trees, and with some delay with respect to LFDI. However, the higher sensitivity of these parameters for reflecting water-stress situations, promoted significant differences that were noted before those of $\Psi_{\text {Stem }}$ and $g_{s}$. In relation to LFDI treatment, Pn significantly increased while $T_{C}$ decreased during the irrigation periods.

The pattern of the physiological variables resulted in different relationships among them. In this sense, especially remarkable were the exponential relations of $\Psi_{\text {Stem }} v s$. $g_{S}$ and $\Psi_{\text {Stem }} v s . \mathrm{P}_{\mathrm{n}}$ (Fig. 5). On the other hand, the photosynthesis rate showed highly significant correlations with $T_{C}$ and $g_{S}$, evidencing its relationship. Finally, $\mathrm{T}_{\mathrm{C}}$ was highly correlated with $\mathrm{g}_{\mathrm{S}}$ and $\Psi_{\text {Stem }}$, indicating linear relationships. Many authors have shown highly significant correlations among $\Psi_{\text {Stem }}, g_{\mathrm{S}}$, and $\mathrm{P}_{\mathrm{n}}$ such as Naor et al., [25] in apple, Marsal et al., [26] in pear, or Naor [27] in plum.

In addition, Ferreira et al., [28] and Valancogne et al., [29] reported strong correlations between crop transpiration and $\Psi_{\text {Stem }}$ in peach, plum, apple, and walnut; although these relationships changed over the seasons, implying that thresholds values for irrigation scheduling may change over the season as well.

On the other hand, the sensitivity of different water stress indicators appears to be related to the degree of change in 


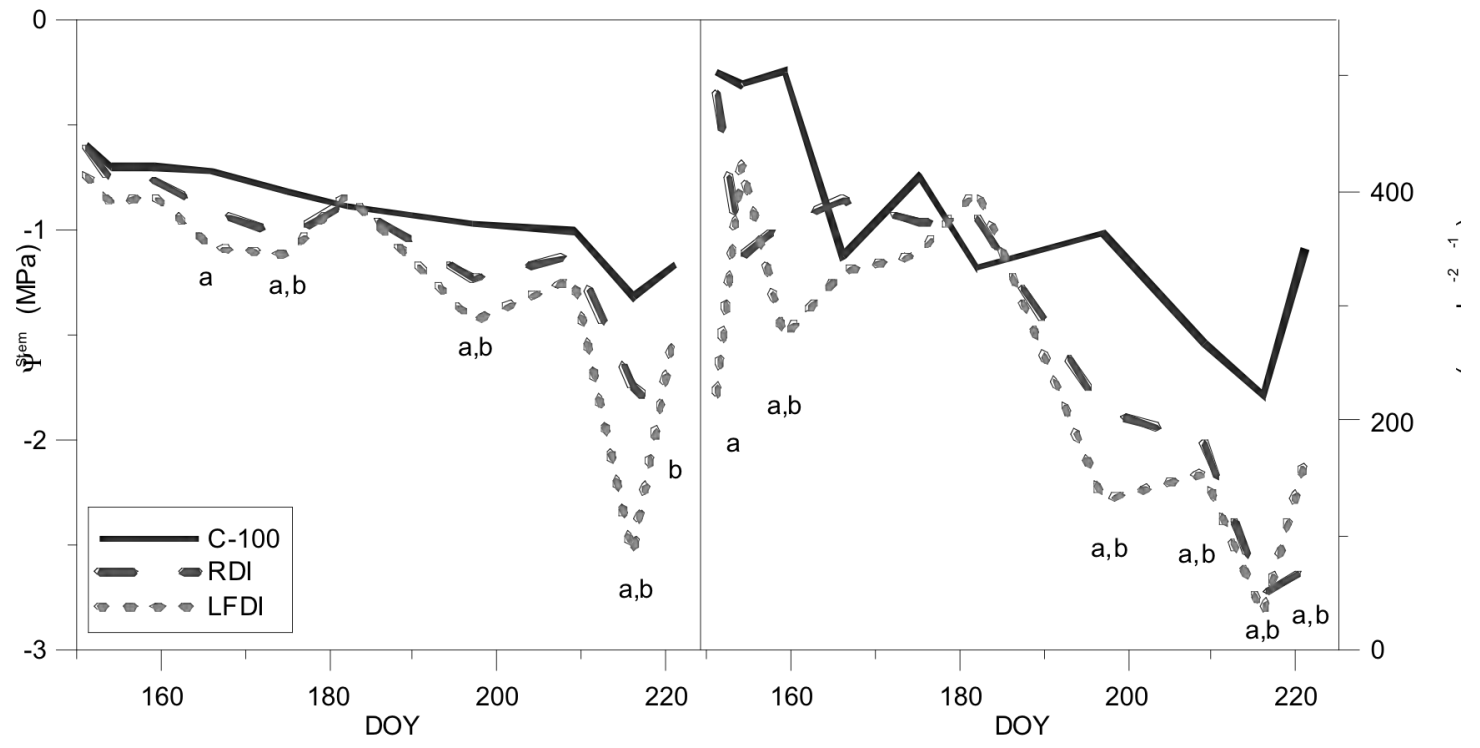

Fig. (3). Time course of stem-water potential $\left(\Psi_{\mathrm{Stem}}\right)$ and stomatal conductance $\left(\mathrm{g}_{\mathrm{S}}\right)$ during the study period. C-100, control treatment; RDI, regulated deficit-irrigation treatment; LFDI, low-frequency deficit-irrigation treatment. ' $\mathrm{a}$ ' and ' $\mathrm{b}$ ' show significant differences for $\mathrm{C}$ - 100 with RDI and LFDI, respectively.

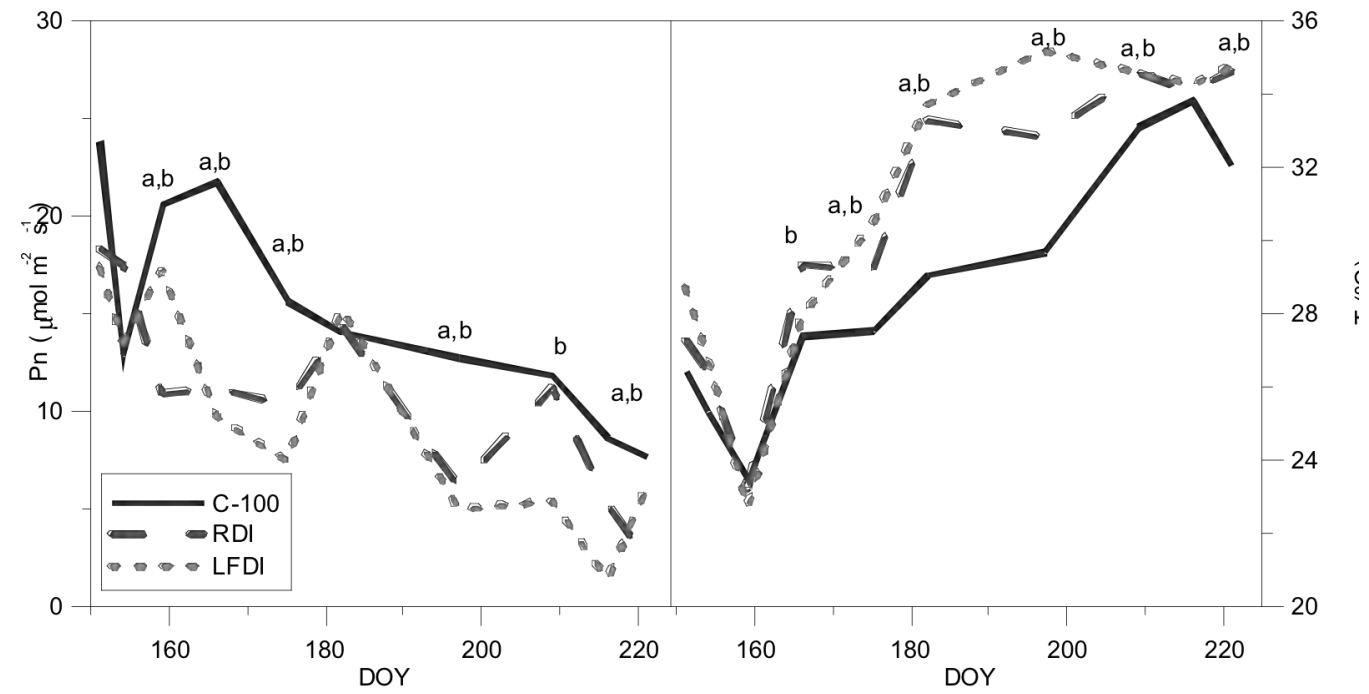

Fig. (4). Time course of photosynthesis rate $\left(\mathrm{P}_{n}\right)$ and canopy temperature $\left(\mathrm{T}_{\mathrm{C}}\right)$ during the study period. C-100, control treatment; RDI, regulated deficit-irrigation treatment; LFDI, low-frequency deficit-irrigation treatment. ' $\mathrm{a}$ ' an ' $\mathrm{b}$ ' show significant differences for $\mathrm{C}$ - 100 with RDI and LFDI, respectively.

water status that can be detected statistically, i.e. the least significant difference for a given number of measurements. In this sense, the sensitivity of a water-stress indicator is expected to increase with the level of response of the sensor to changes in water status, and to decrease with increasing variability between sensors/readings [30]. In contrast to our findings, Remorini and Massai [31] argued that $\mathrm{T}_{\mathrm{C}}$ was less sensitive to a water-stress situation than was $\Psi_{\text {Stem. }}$. However, in line with these results, water stress was detected earlier with $\Psi_{\text {Stem }}$ than with transpiration rate, although these findings are not definitive.

Given the experimental location (very close to the riverbed), and the high crop capacity to adapt to water-stress conditions, the soil-water content was monitored at different depths (Fig. 6). The main differences between treatments were found to occur at $30 \mathrm{~cm}$ of soil depth, especially during the restriction periods in LFDI. Also, there was a noticeable absence of differences between RDI and control trees, which would explain the scarcity of significant differences between these treatments in relation to the plant physiological parameters.

The soil-water contents registered in the deepest zones showed an absence of differences between treatments, and with values close to field capacity. This situation could explain the moderate crop physiological response, which, despite the detection of significant differences, was not patent throughout the kernel-filling stage.

In relation to the impact of DI on nut yield, the results showed that LFDI was the most effective treatment, improving the results of RDI and control trees. In this context, RDI showed a final yield of $1,100 \mathrm{~kg} \mathrm{ha}^{-1}$ whereas C-100 and LFDI reflected final nut yield of 1,600 and 1,800 

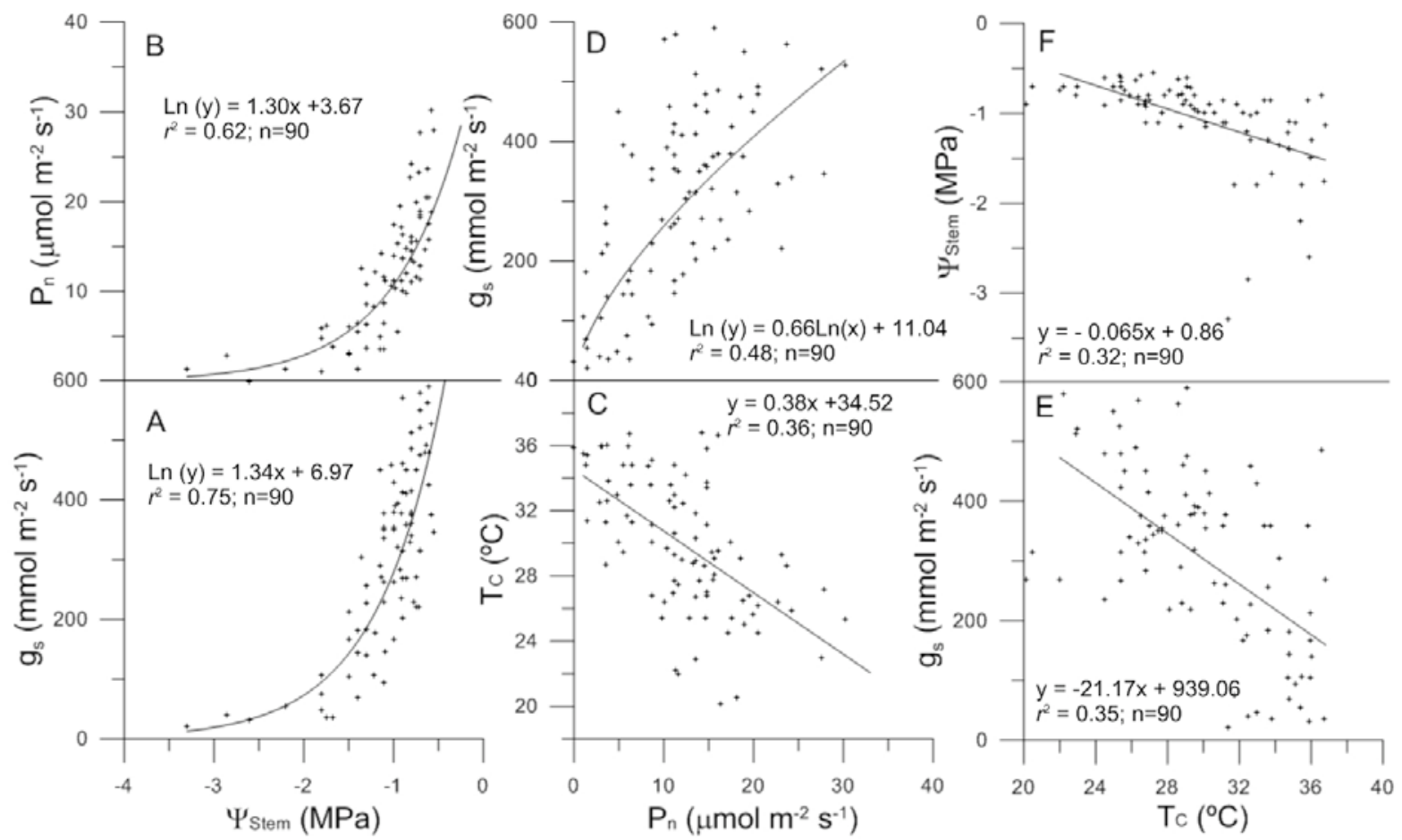

Fig. (5). Relationships among plant physiological parameters. $\Psi_{\text {Stem }}$, stem-water potential; $g_{s}$, stomatal conductance; $P_{n}$, photosynthesis rate; $\mathrm{T}_{\mathrm{C}}$, canopy temperature.

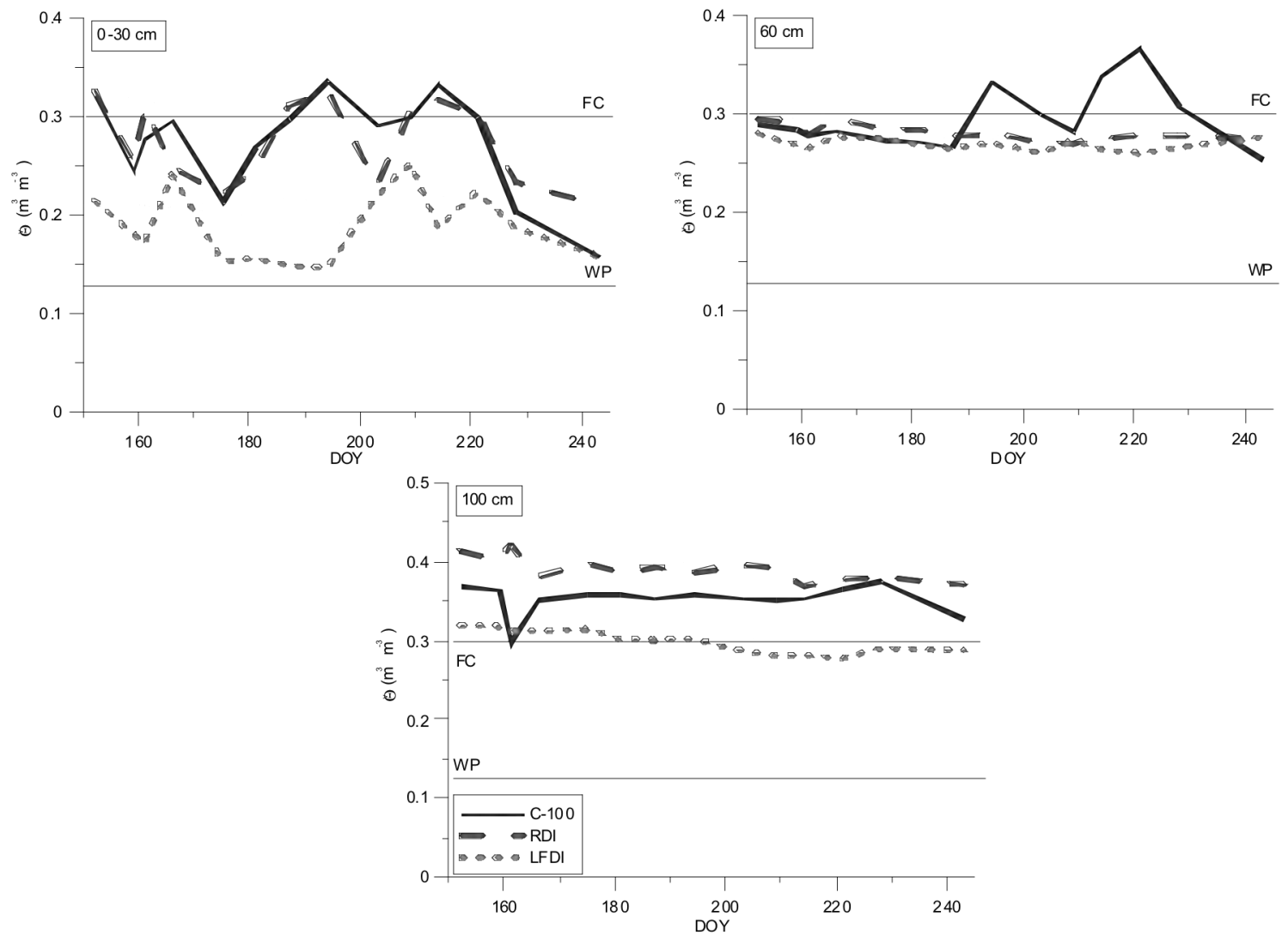

Fig. (6). Soil-water-content dynamics at different depths. C-100, control treatment; LFDI, low-frequency deficit irrigation; RDI, regulated deficit irrigation; FC, field capacity; WP, wilting point.

$\mathrm{kg} \mathrm{ha}^{-1}$, respectively (Fig. 7). Regarding the weight ratio of kernel vs. almond shell, better results were found in LFDI with a 40 and $38 \%$ for RDI and C-100, respectively.
In line with this finding, several authors have shown the advantages of RDI in almond trees when water stress is applied during kernel filling, without significant yield 
reduction [6, 16]. Also, Goldhamer et al., [7] argued that kernel growth was reduced when a severe pre-harvest water stress was applied, this lowering kernel weight and thus the final yield.

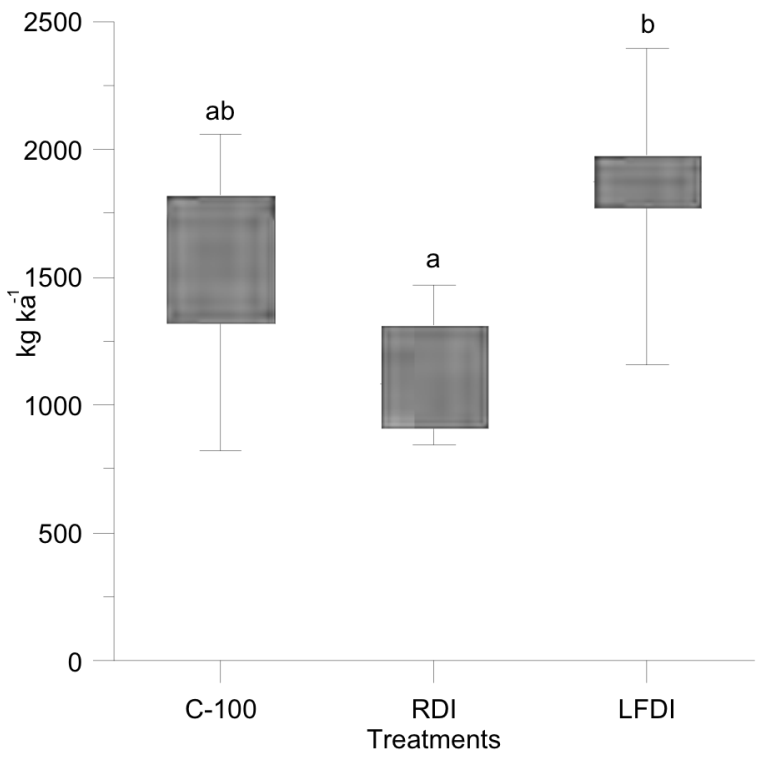

Fig. (7). Nut yield in each treatment. C-100, control treatment, RDI, regulated deficit irrigation; LFDI, low-frequency deficit irrigation. Different letters indicate significant differences at $p<0.05$. Vertical bars represent the standard deviation.

In addition, there were remarkable the effects of DI in terms of water-use efficiency (WUE). In this line, C-100 registered a WUE of $203.64 \mathrm{~g} \mathrm{~m}^{-3}$, whereas RDI registered lower closely to $175.89 \mathrm{~g} \mathrm{~m}^{-3}$. Especially remarkable were the WUE for LFDI, being significantly better than those determined in C-100 and RDI, with about $476 \mathrm{~g} \mathrm{~m}^{-3}$. In this context, García-Tejero et al., [13] showed substantial improvements in WUE under the LFDI strategy applied to citrus trees, in comparison to regulated or sustained deficit irrigation.

Thus, our findings support the agronomic and environmental benefits of low-frequency deficit irrigation $v s$. other strategies such as sustained or regulated deficit irrigation.

According to the results of the present study, we concluded that the low-frequency deficit irrigation is a viable and sustainable management strategy for limited water resources in the almond crop in semiarid regions.

\section{ACKNOWLEDGEMENT}

None declared.

\section{CONFLICT OF INTEREST}

None declared.

\section{REFERENCES}

[1] FAOSTAT Food and agriculture organization of the United Nations. Available in: http://faostat.fao.org/. [accessed: September 2011].
[2] Micke W, Kester D. Almond Orchard Management. Division of agricultural sciences, 1978; University of California.

[3] Castel JR, Fereres E. Responses of young almond trees to two drought periods in the field. J Hortic Sci 1982; 57: 175-87.

[4] Marsal J, Girona J, Mata M. Leaf water relation parameters in almond compared to hazelnut trees during a deficit irrigation period. J Am Soc Hortic Sci 1997; 122: 582-87.

[5] Nanos GD, Kazantzis I, Kefalas P, Petrakis C, Stravroulakis GG. Irrigation and harvest time affect almond kernel quality and composition. Sci Hortic 2002; 96: 246-56.

[6] Girona J, Mata M, Marsal J. Regulated deficit irrigation during the kernel filling. period and optimal irrigation rates in almond. Agric Water Manag 2005; 75: 152-67.

[7] Goldhamer DA, Viveros M, Salinas M. Regulated deficit irrigation in almonds: effects of variations in applied water and stress timing on yield and yield components. Irrig Sci 2006; 24: 101-14.

[8] Girona J, Marsal J. Estrategias de RDC en almendro. In: Riego deficitario controlado. Zapata M., Segura, P, Eds. España. MundiPrensa 1995; 97-118.

[9] Romero O, Botia P, Garcia F. Effects of regulated deficit irrigation under subsurface drip irrigation conditions on vegetative development and yield of mature almond trees. Plant Soil 204; 260 169-81.

[10] Hsiao T, Steduto P, Fereres E. A systematic and quantitative approach to improve water use efficiency in agriculture. Irrig Sci 2007; 25: 209-31.

[11] Turner NC. Agronomic options for improving rainfall-use efficiency of crops in dryland farming systems. J Exp Bot 2004; 55 2413-25.

[12] Evans LT. Crop evolution, adaptation and yield. Cambridge University Press. 1993; Cambridge, UK.

[13] García-Tejero I, Durán-Zuazo VH, Jiménez JA, Muriel-Fernández JL. Improved water-use efficiency by deficit irrigation programs: Implications for saving water in citrus orchards. Sci Hortic 2011; 128: 274-82.

[14] Shackel KA, Ahmadi H, Biasi W, et al. Plant water status as an index of irrigation need in deciduous fruit trees Hortic Technol 1997; 7: 23-9.

[15] Fulton A, Buchner R, Olson B, et al. Rapid equilibration of leaf and stem water potential under field conditions in almonds, walnuts and prunes. Hortic Technol 2001; 11: 609-15.

[16] Romero P, Botía P. Daily and seasonal patterns of leaf water relations and gas exchange of regulated deficit-irrigated almond trees under semiarid conditions. Environ Exp Bot 2006; 56: 15873.

[17] Idso SB, Jackson RD, Pinter PJ, Reginato RJ, Hatfield JL. Normalizing the stress-degree-day parameter for environmental variability. Agric Meteorol 1981; 24: 45-55.

[18] Jones $\mathrm{H}$. Irrigation scheduling: advantages and pitfalls of plantbased methods. J Exp Bot 2004; 55: 2427-36.

[19] Jones H. Monitoring plant and soil water status: established a novel revisited and their relevance to studies of drought tolerance. J Exp Bot 2007; 58: 119-30.

[20] Scholander PF, Hammel HT, Hemingsen EA, Bradstreet ED. Hydrostatic pressure and osmotic potential of leaves of mangrove and some other plants. Proc Natl Acad Sci USA 1964; 52: 119-25.

[21] Turner NC. Measurements of plant water status by pressure chamber technique. Irrig Sci 1988; 9: 289-308.

[22] Goldhamer DA, Fereres E. Irrigation scheduling of almond trees with trunk diameter sensors. Irrig Sci 2004; 23: 11-9.

[23] Romero O, Botia P, Garcia F. Effects of regulated deficit irrigation under subsurface drip irrigation conditions on water relations of mature almond trees. Plant Soil 2004; 260: 155-68.

[24] García-Tejero I, Durán-Zuazo VH, Muriel-Fernández JL, JiménezBocanegra JA. Linking canopy temperature and trunk diameter fluctuations with other physiological water status tools for water stress management in citrus orchards. Funct Plant Biol 2011; 38: 106-17.

[25] Naor A. Relationships between leaf and stem water potentials and stomatal conductance in three field-grown species. J Hort Sci Biotech 1998; 73: 431-36.

[26] Marsal J, Mata M, Arbonés A, Rufat J, Girona J. Water stress limits for vegetative and rfeproductive growth of 'Barlett' pears. Acta Hortic 2002; 596: 659-64. 
[27] Naor A. The interactions of soil and item-water potentials with crop level, fruit size and stomatal conductance of field-grown 'Black Amber' Japanese plum. J Hortic Sci Biotech 2004; 79: 273 80.

[28] Ferreira MI, Pacheco CA, Valancogne C, Michaelson J, Ameglio T, Daudet FA. Evapotranspiration, water stress indicators and soil water balance in a Prunus persica orchard in central Portugal. Acta Hortic 1997; 449: 379-84.
[29] Valancogne C, Dayau S, Ferreira-Gama MI, et al. Relations between relative transpiration and predawn leaf water potential in different fruit tree species. Acta Hortic 1997; 449: 423-29.

[30] Naor A. Irrigation Scheduling and evaluation of tree water status in deciduous orchards. In: Janick, J, Ed. Hortic Rev 2006; 32: 111-65.

[31] Remorini D, Massai R. Comparison of water status indicators for young peach trees. Irrig Sci 2003; 22: 39-46.

Received: October 18,2011

(C) García-Tejero et al.; Licensee Bentham Open.

This is an open access article licensed under the terms of the Creative Commons Attribution Non-Commercial License (http://creativecommons.org/licenses/by$\mathrm{nc} / 3.0 /$ ), which permits unrestricted, non-commercial use, distribution and reproduction in any medium, provided the work is properly cited. 